\title{
The freshwater amphipods Hyalella Smith, 1874 in Chile (Crustacea: Amphipoda)
}

\author{
Los anfípodos de agua dulce del género Hyalella Smith, 1874 en Chile \\ (Crustacea: Amphipoda)
}

EXEQUIEL R. GONZÁLEZ ${ }^{1,2}$

\begin{abstract}
${ }^{1}$ Facultad de Ciencias del Mar, Universidad Católica del Norte, Casilla 117, Coquimbo, Chile; e-mail egonzale@ucn.cl ${ }^{2}$ Centro de Estudios Avanzados en Zonas Áridas (CEAZA), Coquimbo, Chile
\end{abstract}

\begin{abstract}
The Chilean fauna of amphipods has been poorly studied. Freshwater amphipods in Chile have a single genus in epigean environments. Seven species of the genus Hyalella are reported for Chile: H. simplex; H. fossamancinii, H. kochi; H. chiloensis; H. costera; H. araucana, and H. franciscae. A short diagnosis, a key and figures are given for each species.
\end{abstract}

Key words: Neotropical, Amphipoda, Hyalella, Chile, freshwater.

\section{RESUMEN}

La fauna de anfípodos chilenos ha sido pobremente estudiada. En el caso de los de agua dulce y de ambientes epigeos, el grupo está representado solo por un género. Se reportan siete especies del género Hyalella para Chile: H. simplex; H. fossamancinii, H. kochi; H. chiloensis; H. costera; H. araucana, y H. franciscae. Se entrega una breve diagnosis, una clave y figuras para cada especie.

Palabras clave: neotropical, Amphipoda, Hyalella, Chile, agua dulce.

\section{INTRODUCTION}

The species in the genus Hyalella Smith, 1874 have been poorly studied and they had a confusing taxonomic state, in Chile and America, as a whole. Eleven species have been recorded for Chile, $H$. gracilicornis (Faxon, 1876) and H. curvispina Shoemaker, 1942 (in Barnard \& Barnard 1983); H. azteca (Saussure, 1858) (in Ruffo 1947, González 1991a); $H$. simplex Schellenberg, 1943; H. fossamancinii Cavalieri, 1959 (in González \& Watling 2001), H. dentata inermis (Faxon, 1876); H. kochi González \& Watling, 2001; H. chiloensis González \& Watling, 2001; H. costera González \& Watling, 2001; H. araucana Grosso \& Peralta, 1999; and H. franciscae González \& Watling, 2003a.

The first record of freshwater amphipods in Chile corresponded to Amphithoe andina Philippi, 1860 from high elevations in the Atacama desert, Chile. Unfortunately the description is very poor and no drawings were included. This species and $H$. dentata inermis were synonymized under $H$. inermis Smith, 1875 by Stebbing (1906). Later Barnard \& Barnard (1983) synonymized A. andina under $H$. gracilicornis, indicating that it was different from $H$. inermis; no mention of $H$. dentata inermis was made. This suggested that $H$. gracilicornis was the species described by Philippi (1860) and distributed in northern Chile (González 1991b). However, it is important to stress that the type locality of $H$. gracilicornis is a channel at Campos, Rio de Janeiro, Brazil. Schellenberg (1931) studied freshwater amphipods from Quilpue, Putabla, Puerto Montt and Punta Arenas in Chile, as well as material from Montevideo, Uruguay, Islas Malvinas, Santa Cruz and Usuahia in Argentina. Schellenberg identified these specimens as H. knickerbockeri (Bate, 1862). In a later publication, Schellenberg (1943) determined that the material represented a new species which he named $H$. simplex. Barnard \& Barnard (1983) synonymized H. simplex under H. curvispina. Bousfield (1996) considered both as valid species. González \& Watling 
(2003a) redescribed $H$. simplex and considered the species valid. González (1991a, 1991b) assigned most of the Chilean specimens of Hyalella to $H$. gracilicornis, however, in some areas he thought $H$. azteca could also be present. Three new species were described by González \& Watling (2001), H. kochi for the andean north and central zone of Chile; $H$. costera for lowlands from Paposo (Antofagasta) to Valdivia; and $H$. chiloensis from Concepción to Coihaique.

Hyalella fossamancinii, Cavalieri, 1959, $H$. araucana Grosso \& Peralta, 1999, and $H$. franciscae González \& Watling, 2003a are part of what has been called the "patagonica complex". This group is named after $H$. patagonica (Cunningham, 1871) the first described species of the complex. Most of the species have a rather restricted distribution in the extreme south of South America. Bousfield (1996) proposed for Chile in this complex, species "A" now $H$. araucana, species "B" now H. franciscae and species " $\mathrm{C}$ " not described yet
(González \& Watling 2003a). Hyalella araucana was described as nomen novum by Grosso \& Peralta 1999 in replacement of $H$. patagonica.

Here a short description is given for the seven valid species recorded in Chile. The figures in this work are modified from the original descriptions. A discussion of the species previously recorded for Chile is also included.

\section{TAXONOMY}

Hyalella araucana Grosso \& Peralta, 1999 (Fig. 1)

Hyalella araucana Grosso \& Peralta, 1999: 84, 86 , 88, figs. 22-45.

Allorchestes patagonicus Cunnigham, 1871: 498, pl. LIX. fig. 14; Stebbing, 1906: 585 (in part).

Hyalella patagonicus Stebbing, 1888: 404.

Hyalella patagonica Ortmann, 1911: 650-
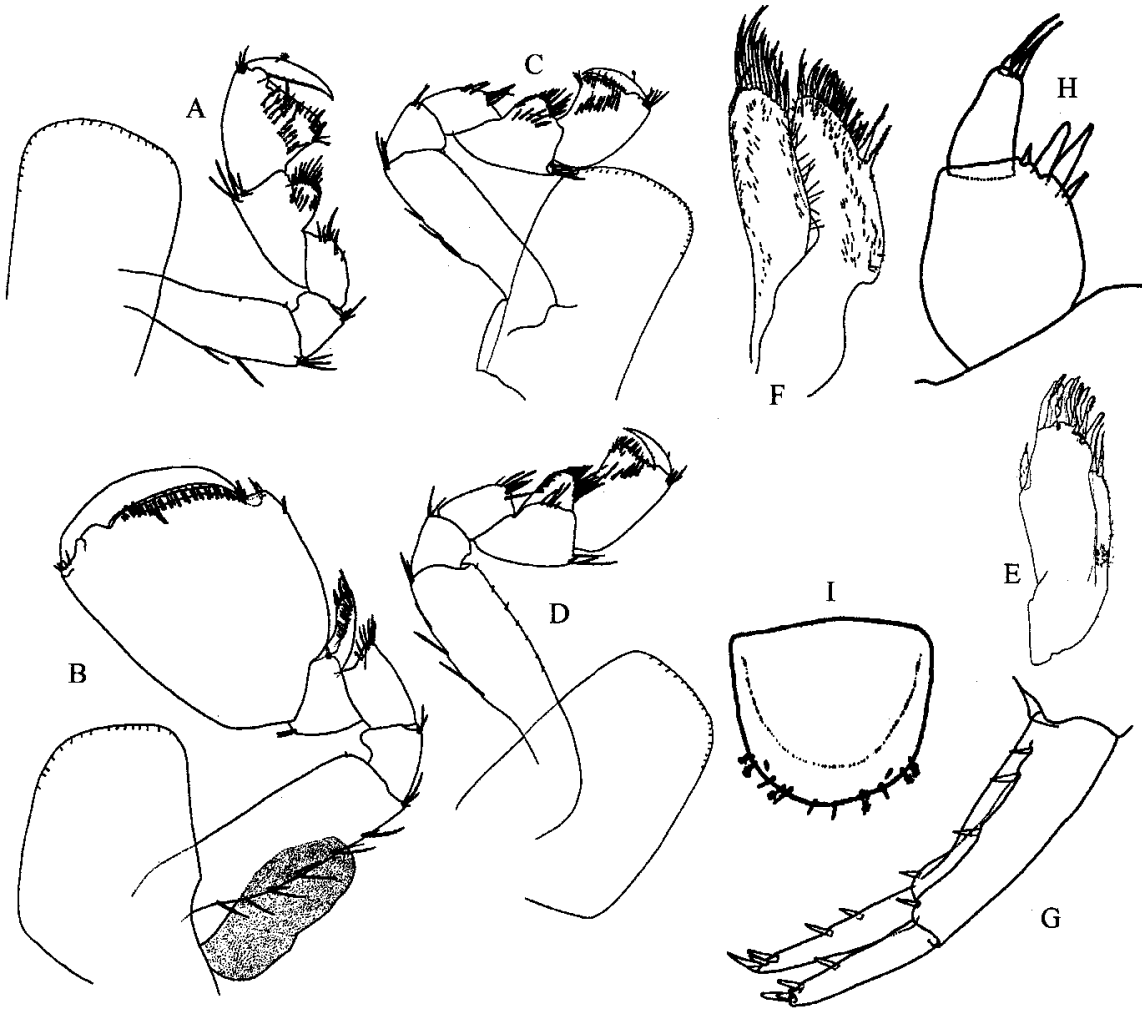

Fig. 1: Hyalella araucana, male length $11.1 \mathrm{~mm}$, female $9.8 \mathrm{~mm}$. Modified from Grosso \& Peralta (1999). Symbols of figures are: (A) gnathopod 1 male; (B) gnathopod 2 male; (C) gnathopod 1 female; (D) gnathopod 2 female; (E) maxilla 1; (F) maxilla 2; (G) uropod 1; (H) uropod 3; (I) telson.

Hyalella araucana, macho, largo11,1 mm, hembra 9,8 mm. Modificado de Grosso \& Peralta (1999). Símbolos para las figuras son como sigue: (A) gnatópodo 1 macho; (B), gnatópodo 2 macho; (C) gnatópodo 1 hembra; (D) gnatópodo 2 hembra; (E) maxila 1; (F) maxila 2; (G) urópodo 1; (H) urópodo 3; (I) telson. 
657, fig. 3a-h (in part); Stebbing, 1914: 368; Schellenberg, 1943: 204.

Hyalella patagonica Schellenberg, 1931: 227, fig. 115 (in part); Barnard \& Barnard, 1983: 709; Bousfield, 1996: 188; not Hyalella neonoma Stock \& Platvoet, 1991: 1486, figs. 12-14.

Type material: Museo Cívico di Storia Naturale di Verona, Italy. Type locality: Río de los Dervos, Chile (probably Río de los Ciervos, Chile). Material Examined. Lago de los Ciervos, Punta Arenas (53 $11^{\prime}$ S, $\left.70^{\circ} 56^{\prime} \mathrm{W}\right)$, Lago Sarmiento, Torres del Paine $\left(51^{\circ} 04^{\prime} \mathrm{S}, 72^{\circ} 45^{\prime} \mathrm{W}\right)$.

Diagnosis: body surface smooth. Coxa 4 excavated posteriorly. Eyes pigmented. Antenna 1 shorter than antenna 2. Mandible incisor toothed. Maxilla 1 palp longer than wide, reaching more than half length the distance between base of palp and tip of setae on outer plate; inner plate slender, with two strong and pappose apical setae. Maxilla 2 inner plate with two apposed strong pappose setae on inner margin (Fig. 1F). Gnathopod 1 propodus length less than two times maximum width (quadrangular), hatched shape, inner face with ten pappose setae, disto-posterior and disto-anterior borders without setose scales. Gnathopod 2 propodus ovate, palm length the same as posterior margin, slope slightly oblique, anterior edge smooth. Peraeopods 3 and 4 merus and carpus posterior margin with three hind marginal clusters of short setae; propodus posterior margin with two to four groups of setae. Uropod 3 peduncle with four strong distal setae; outer ramus shorter than peduncle, basal width two times or less tip of ramus. Telson as wide as long, apically rounded, with more than two small or minute setae, asymmetrically distributed on the apical margin. Sternal gills in segments 3 to 7 .

Characters of female that differ from male. Size, $9.8 \mathrm{~mm}$. Antenna 1 flagellum with seven articles. Antenna 2 weaker than in male, flagellum with eight articles. Gnathopod 1 similar in size, and different in shape to gnathopod 2; similar to male gnathopod 1 in size and shape. Gnathopod 2 different from male gnathopod 2 in shape and smaller, propodus length less than two times maximum width, normally subchelate, palm transverse.

Habitat. Freshwater, epigean, littoral.

Distribution: Río de los Dervos (probably Río de los Ciervos), Chile, South America.

Remarks. This species was erected as a nomen novum for $H$. patagonica (Cunningham, 1871), which is not described in the original paper and poorly figured. Grosso \& Peralta (1999) gave a long list of characters for distinguishing this species from $H$. neonoma. The species are very close, but differ among other characters, in the length of palp in maxilla 1, setation and palm border in propodus of gnathopod 2 in male, and setation of peduncle in uropod 3. The figures of $H$. sp. A given by Bousfield (1996) correspond well with this species.

Hyalella chiloensis González \& Watling, 2001 (Fig. 2)

Hyalella chiloensis González \& Watling, 2001: 177-183, figs. 1-4.

Type locality: Notuco, Chiloé, Chile. Material Examined: Notuco, Chiloé, Chile.

Diagnosis: body surface smooth. Coxa 4 excavated posteriorly. Eyes pigmented. Antenna 1 shorter than antenna 2. Antenna 2 less than half body length. Mandible incisor toothed. Maxilla 1 palp minute, reaching less than half length the distance between base of palp and tip of setae on outer plate; inner plate slender, with two strong and pappose apical setae. Maxilla 2 inner plate with one strong pappose seta on inner margin (Fig. 2F). Gnathopod 1 propodus length less than two times maximum width (quadrangular), hammer shape, inner face with nine pappose setae, setose scales on disto-posterior and distoanterior border. Gnathopod 2 propodus ovate, palm length the same as posterior margin, slope slightly oblique, anterior edge smooth. Peraeopods 3 and 4 merus and carpus posterior margin with five to six hind marginal clusters of long setae; propodus posterior margin with five to eight groups of setae. Uropod 3 peduncle with four strong distal setae; outer ramus longer than peduncle, basal width two times or less tip of ramus. Telson longer than wide, apically truncated, with more than two, long and short simple setae symmetrically distributed in two groups, occasionally with shorter setae close to the main setae. Sternal gills in segments 3 to 7 .

Characters of females that differ from males: Size, $7.4 \mathrm{~mm}$. Antenna 1 flagellum with six articles. Antenna 2 similar in shape to male, flagellum with nine articles. Gnathopod 1 similar in size, and same shape to gnathopod 2; similar to male gnathopod 1 in size and shape. Gnathopod 2 different from male gnathopod 2 in shape and smaller, propodus length two to three times maximum width, normally subchelate, palm transverse.

Habitat. Freshwater, epigean, littoral.

Distribution: Laguna Redonda, Concepción, to Río Nirepan, Cohaique, Chile, South America.

Remarks: This species is close to $H$. curvispina in its general morphology, 


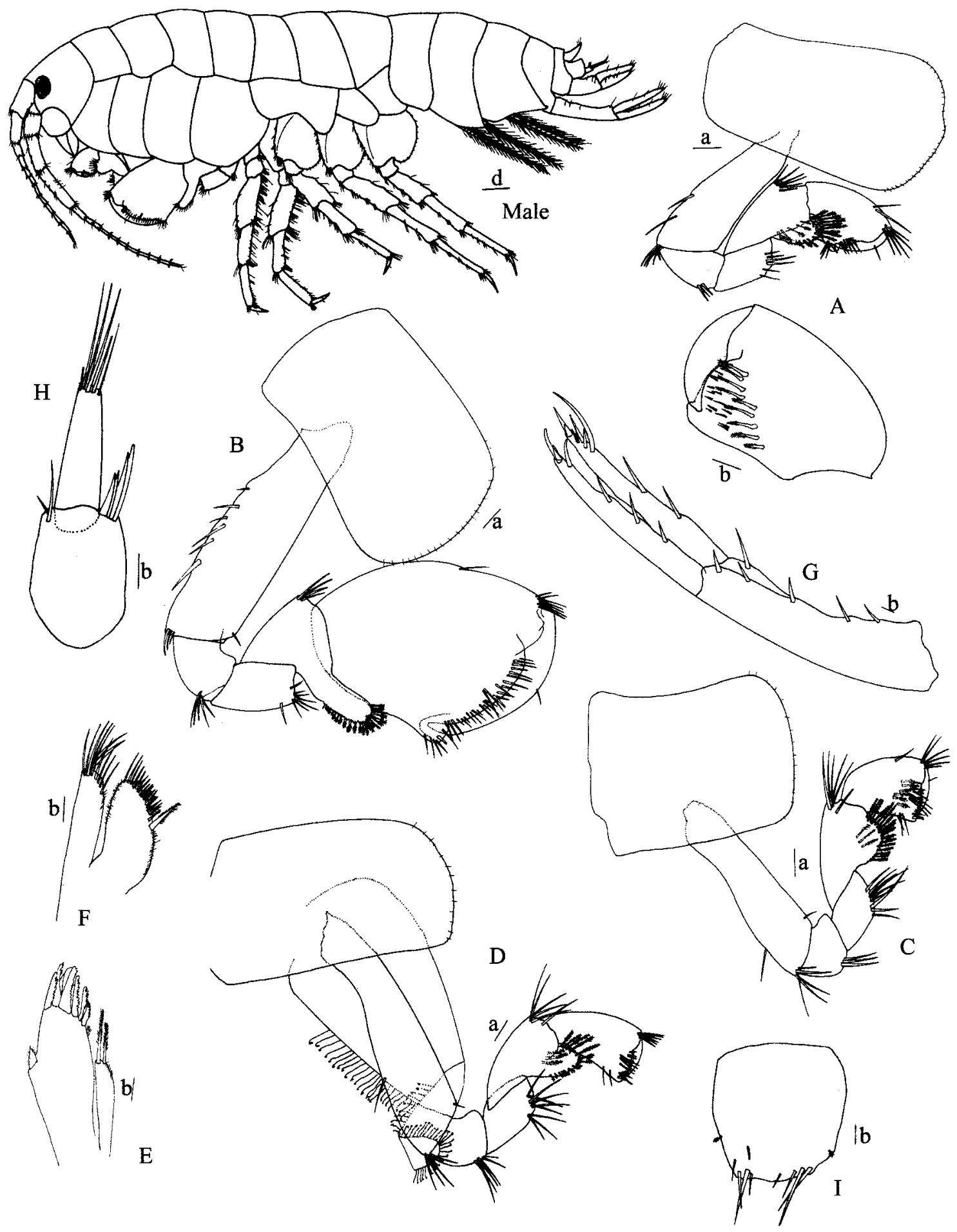

Fig. 2: Hyalella chiloensis male, length $8.1 \mathrm{~mm}$, female $7.4 \mathrm{~mm}$. Modified from González \& Watling (2001). Symbols as in Fig. 1. The scale is indicated as a small bar on each appendices: "a" is equivalent to $103 \mu \mathrm{m}$; "b" is equivalent to $50 \mu \mathrm{m}$; "d" is equivalent to $330 \mu \mathrm{m}$.

Hyalella chiloensis macho, largo 8,1 mm, hembra 7,4 mm. Modificado de González \& Watling (2001). Símbolos como en Fig. 1. La escala de tamaño esta indicada por una pequeña barra en cada apéndice: "a" es equivalente a $103 \mu \mathrm{m}$; "b" es equivalente a $50 \mu \mathrm{m}$; "d" es equivalente a $330 \mu \mathrm{m}$. 
especially uropod 3, and gnathopods, but differs in the type of setae on the telson, $(H$. curvispina has shorter and stronger setae on telson), a shorter article 2 in maxillipedal palp, males bear nine setae on inner side of propodus in gnathopod 1 , and longer setae on merus and carpus in peraeopods 3 and 4 (see Shoemaker 1942). The main characteristic that distinguishes these two species is the presence of six pairs (from segment 2 to 7 ) of sternal gills in $H$ curvispina, while $H$. chiloensis has only five pairs (from segment 3 to 7). This feature has been overlooked by or not considered of importance by many authors (Ruffo 1947), or miscounted in several descriptions. The consistency of this character makes it relevant in the evolutionary relationships within the genus.

Hyalella costera González \& Watling, 2001 (Fig. 3)

Hyalella knicherbockeri Schellenberg, 1931: 228, fig. 116 (in part), not drawings, [not

Allorchestes knicherbockeri Bate 1862: 36, plate VI fig. 1].

? Hyalella knicherbockeri inermis Schellenberg, 1935: 229.

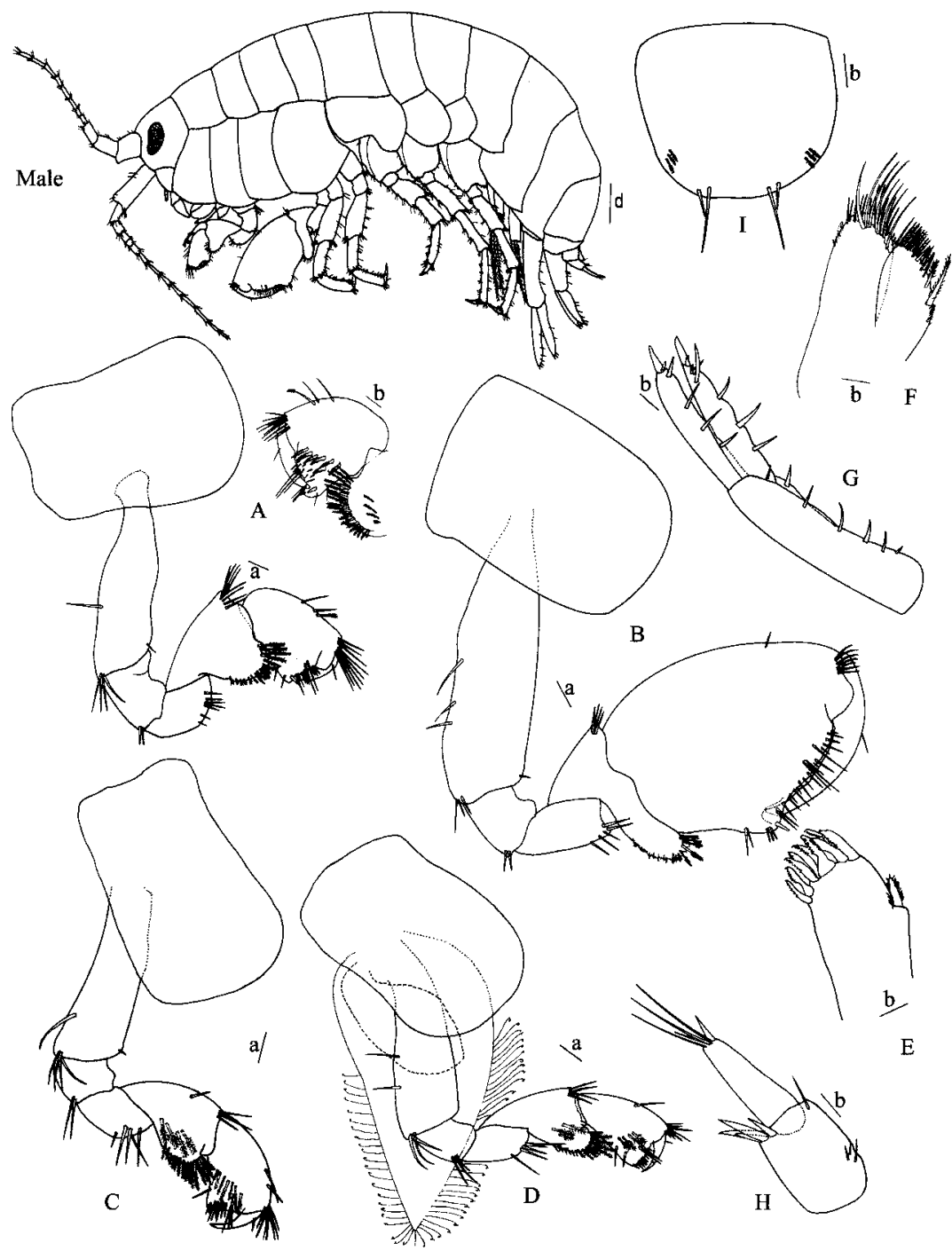

Fig. 3: Hyalella costera male, length $7.1 \mathrm{~mm}$, female $6.1 \mathrm{~mm}$. Modified from González \& Watling (2001). Symbols and scale as in Fig. 2.

Hyalella costera macho, largo 7,1 mm, hembra 6,1 mm. Modificado de González \& Watling (2001). Símbolos y escala como en Fig. 2. 
Hyalella simplex Schellenberg, 1943: 201 (in part). [not Hyalella simplex f. cangallensis Schellenberg, 1943: 201, fig. 1].

Hyalella azteca Barnard \& Barnard, 1983: 708 (in part); González, 1991a: 56 (in part).

Hyalella curvispina Barnard \& Barnard, 1983: 708 (in part)

Hyalella costera González \& Watling, 2001: 183-191, figs. 5-10.

Type locality: Quebrada Paposo, Antofagasta, Chile. Material examined: Quebrada Paposo, Antofagasta, Limache, El Molle.

Diagnosis: body surface smooth. Coxa 4 excavated posteriorly. Eyes pigmented. Antenna 1 shorter than antenna 2. Antenna 2 less than half body length. Mandible incisor toothed. Maxilla 1 palp longer than wide, reaching half length the distance between base of palp and tip of setae on outer plate; inner plate slender, with two strong and pappose apical setae. Maxilla 2 inner plate with one strong pappose seta on inner margin. Gnathopod 1 propodus length less than two times maximum width (quadrangular), hammer shape, inner face with seven pappose setae, setose scales on disto-posterior and distoanterior border. Gnathopod 2 propodus rectangular elongated, palm shorter than posterior margin, slope oblique, anterior edge smooth. Peraeopods 3 and 4 merus and carpus posterior margin with three hind marginal clusters of short setae; propodus posterior margin with two to four groups of setae. Uropod 3 peduncle with four strong distal setae; outer ramus longer than peduncle, basal width two times or less tip of ramus. Telson as wide as long, apically rounded, with two widely apart, long simple setae, symmetrically distributed, occasionally with shorter setae close to the main setae. Sternal gills in segments 3 to 7 .

Characters of females that differ from males. Size, $6.1 \mathrm{~mm}$. Antenna 1 flagellum with eight articles. Antenna 2 similar in shape to male, flagellum with nine articles. Gnathopod 1 similar in size, and same shape to gnathopod 2; similar to male gnathopod 1 in size and shape. Gnathopod 2 different from male gnathopod 2 in shape and smaller, propodus length two to three times maximum width, normally subchelate, palm transverse. Additionally, coxa 6 , anterior lobe is very small; maxilla 2 , inner plate subequal in length to outer plate; maxilliped, article 2 as wide as long; gnathopod 1 propodus with one or two setae on anterior border, inner face without small triangular setae; peraeopod 5 basis posterior lobe deeper than wide and similar to posterior lobe of peraeopod 7, which is wider than deep; uropod 3 with six simple apical slender setae.

Habitat: freshwater, epigean, littoral. Distribution: Quebrada de Paposo, Antofagasta to Isla Teja, Valdivia, Chile, South America.

Remarks: this species was collected in freshwater sources near the coast, along most of the continental Chilean territory. It is the only species present in lowland areas from Paposo in Antofagasta to Concepción. From this point south and down to Valdivia, it is found in the same areas as $H$. chiloensis, but rarely together in the same locality. Most of the specimens collected were females. Only in La Ligua and Limache, males were found in very low densities. $H$. costera differs from $H$. chiloensis in the setation on the inner side of propodus in gnathopod 1, narrower propodus on gnathopod 2, the setation of merus and carpus in peraeopods 3 and 4, setation of telson and the epimeral plate 1 . The main difference of $H$. costera with $H$. curvispina is the setation of the telson and like in $H$. chiloensis, it has only five pairs of sternal gills. The morphological characteristics of this species differ considerably from any of the species in the "azteca complex". The latter is mainly distributed in North America, with possible incursions in Central America. The presence of H. azteca in Chile is highly improbable.

\section{Hyalella fossamancinii Cavalieri, 1959 (Fig. 4)}

Hyalella fossamancinii Cavalieri, 1959:278283, figs. 1-4; Barnard \& Barnard, 1983: 708; González \& Watling, 2001: 198.

Hyalella (Mesohyalella) fossamancinii Bousfield, 1996: 192.

? Amphithoe andina Philippi, 1860: 152.

Type material: Museo de La Plata, Argentina. Type locality: San Juan, Argentina, border with Chile, 3,500 m of altitude. Material examined: La Ola, Copiapó, Chile.

Diagnosis: body surface smooth. Coxa 4 excavated posteriorly. Eyes pigmented. Antenna 1 shorter than antenna 2. Antenna 2 less than half body length. Mandible incisor toothed. Maxilla 1 palp longer than wide, reaching more than half length the distance between base of palp and tip of setae on outer plate; inner plate slender, with two strong and pappose apical setae. Maxilla 2 inner plate with one strong pappose seta on inner margin. Gnathopod 1 propodus length less than two times maximum width (quadrangular), hatched shape, inner face with more than ten pappose setae, disto-posterior and disto-anterior borders without setose scales. Gnathopod 2 propodus 

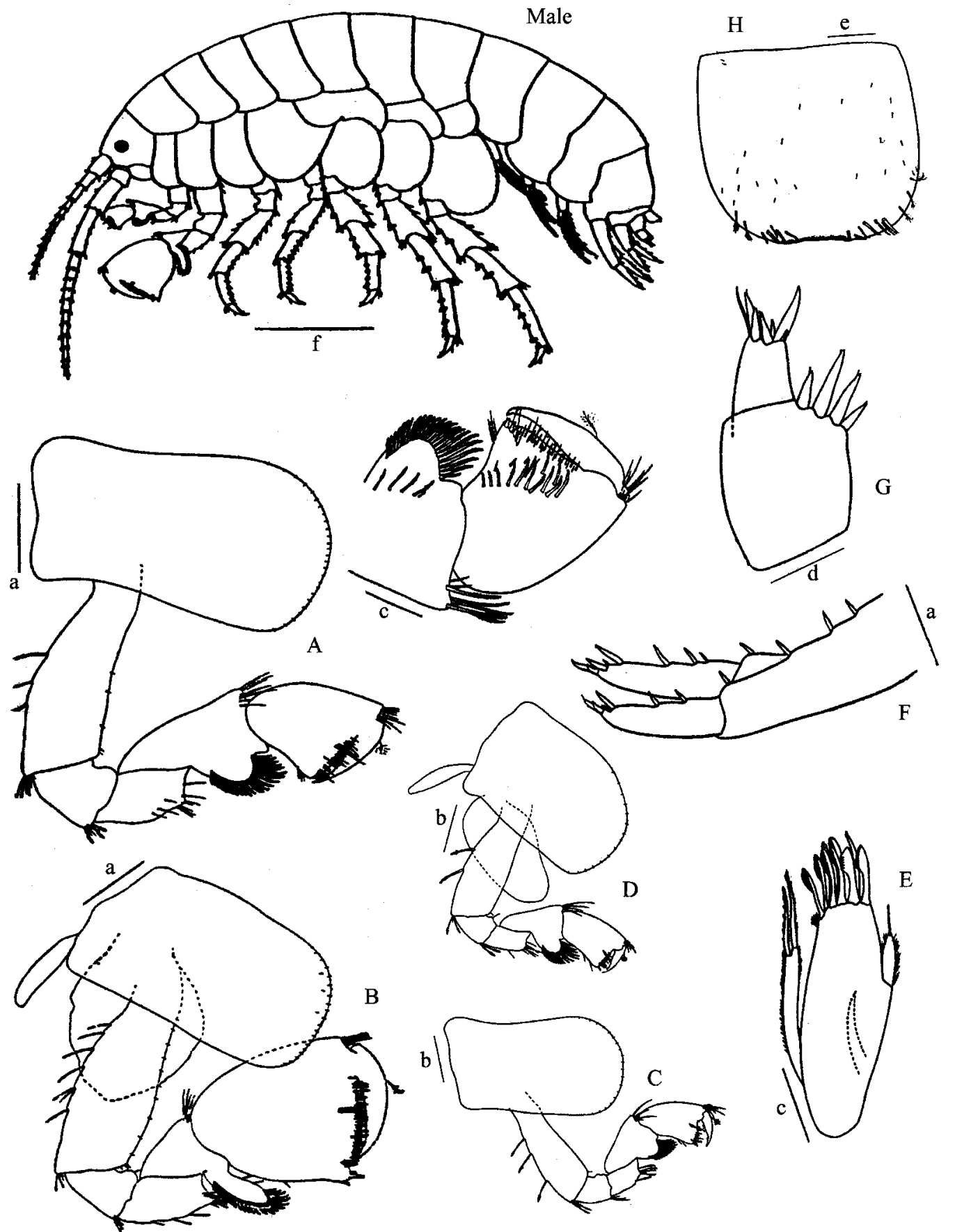

Fig. 4: Hyalella fossamancinii male length $9.4 \mathrm{~mm}$, female $5.6 \mathrm{~mm}$. Modified from Cavalieri (1959). Symbols of figures are: (A), gnathopod 1 male; (B) gnathopod 2 male; (C) gnathopod 1 female; (D) gnathopod 2 female; (E) maxilla 1; (F) uropod 1; (G) uropod 3; (H) telson. The scale is indicated as a small bar on each appendices: "a" is equivalent to $500 \mu \mathrm{m}$; "b" is equivalent to 300 $\mu \mathrm{m}$; "c" is equivalent to $200 \mu \mathrm{m}$; " $\mathrm{d}$ " is equivalent to $150 \mu \mathrm{m}$; "e" is equivalent to $100 \mu \mathrm{m}$; and "f" is equivalent to $2 \mathrm{~mm}$.

Hyalella fossamancinii macho, largo 9,4 mm, hembra 5,6 mm. Modificado de Cavalieri (1959). Símbolos para las figuras son como sigue: (A) gnatópodo 1 macho; (B) gnatópodo 2 macho; (C) gnatópodo 1 hembra; (D) gnatópodo 2 hembra; (E) maxila 1; (F) urópodo 1; (G) urópodo 3; $(\mathrm{H})$ telson. La escala de tamaño esta indicada por una pequeña barra en cada apéndice: "a" es equivalente a $500 \mu \mathrm{m}$; "b" es equivalente a $300 \mu \mathrm{m}$; "c" es equivalente a $200 \mu \mathrm{m}$; "d" es equivalente a 150 $\mu \mathrm{m}$; "e" es equivalente a $100 \mu \mathrm{m}$; and "f" es equivalente a $2 \mathrm{~mm}$. 
ovate, palm length the same as posterior margin, slope slightly oblique, anterior edge smooth. Peraeopods 3 and 4 merus and carpus posterior margin with four hind marginal clusters of short setae; propodus posterior margin with five to eight groups of setae. Uropod 3 peduncle with four strong distal setae; outer ramus shorter than peduncle, basal width two times or less tip of ramus. Telson wider than long, apically quadrate, with more than two small or minute setae, asymmetrically distributed on the apical margin. Sternal gills in segments 3 to 7 .

Characters of female that differ from male. Size, $5.6 \mathrm{~mm}$. Antenna 1 flagellum with eight articles. Antenna 2 similar in shape to male, flagellum with nine articles. Gnathopod 1 similar in size, and same shape to gnathopod 2; similar to male gnathopod 1 in size. Gnathopod 2 different from male gnathopod 2 in shape and smaller, propodus length less than two times maximum width, normally subchelate, palm transverse.

Habitat: freshwater, epigean, littoral. Distribution in Chile: Surire in Arica; Putana river, El Tatio to Salar de Punta Negra in Antofagasta and La Ola, Copiapó.

Remarks. The distribution of this species, in Chile and Argentina, is much northern than the distribution of other members of the "patagonica" group. However, the characteristic hatch shape of propodus in gnathopod 1 represents the common feature for the species complex. The record of $H$. andina (Philippi, 1860) a freshwater amphipod for the Atacama desert (Cachinal de la Sierra, Agua de Profetas (locality not longer exist with this name), and Riofrio), is hardly comparable to any of the species present in Chile. The description is very general and no figures are given. However, the mention of small eyes and triangular gnathopod 1 could put this species closest to $H$. fossamancinii. Since the holotype of $H$. andina is not available and the description is poor, it is better to consider Hyalella andina a nomen dubium. Hyalella. fossamancinii has been recorded for San Juan in Argentina, at high altitude, close to the border with Chile, so it is not surprising to find it in the Chilean part of the Andes. This species is close to $H$. franciscae, for details see the remarks section in the latter species.

Hyalella franciscae González \& Watiling, 2003a (Fig. 5)

Hyalella sp. "B" Bousfield, 1996: 188, fig. 15c. Hyalella franciscae González \& Watiling, 2003a:
Type locality: Laguna El Paso, Torres del Paine, Chile. Material examined: Laguna El Paso, Torres del Paine, Chile.

Diagnosis: body surface smooth. Coxa 4 excavated posteriorly. Eyes pigmented. Antenna 1 shorter than antenna 2. Antenna 2 less than half body length. Mandible incisor toothed. Maxilla 1 palp longer than wide, reaching base of setae on outer plate; inner plate slender, with two strong and pappose apical setae. Maxilla 2 inner plate with one strong pappose seta on inner margin. Gnathopod 1 propodus length less than two times maximum width (quadrangular), hatched shape, inner face with more than ten pappose setae, disto-posterior and disto-anterior borders without setose scales. Gnathopod 2 propodus triangular, palm longer than posterior margin, slope oblique, anterior edge smooth. Peraeopods 3 and 4 merus and carpus posterior margin with four hind marginal clusters of long setae; propodus posterior margin with five to eight groups of setae. Uropod 3 peduncle with five strong distal setae; outer ramus same length as peduncle, basal width more than two times tip of ramus. Telson wider than long, apically rounded, with more than two, long and short simple setae, asymmetrically distributed on the apical margin. Sternal gills in segments 3 to 7 .

Characters of females that differ from males. Size, $11.4 \mathrm{~mm}$. Antenna 1 flagellum with seven articles. Antenna 2 similar in shape to male, flagellum with ten articles. Gnathopod 1 similar in size, and same shape to gnathopod 2 ; similar to male gnathopod 1 in size. Gnathopod 2 different from male gnathopod 2 in shape and smaller, propodus length less than two times maximum width, normally subchelate, palm transverse.

Habitat. Freshwater, epigean, littoral.

Distribution: El Paso, Lago Risopatrón, Laguna Melliza, Laguna Redonda, Laguna Larga, Lago Sarmiento, Patagonia, Chile, South America.

Remarks: this species is close to $H$. fossamancinii, but differs in having 16 setae on the inner face of propodus in gnathopod 1; long setae on posterior margin of merus and carpus of peraeopods 3 and 4; long ramus on uropod 3; long setae on posterior margin of telson; several setae on uropod 1, and bigger eyes. The figures given by Bousfield (1996) of $H$. sp. B correspond well with this species.

Hyalella kochi González \& Watling, 2001 (Fig. 6)

Allorchestes dentata inermis Faxon, 1876: 373, fig. 35 (in part).

Hyalella cf. gracilicornis González, 1991b: 101, fig. 6 (in part). 


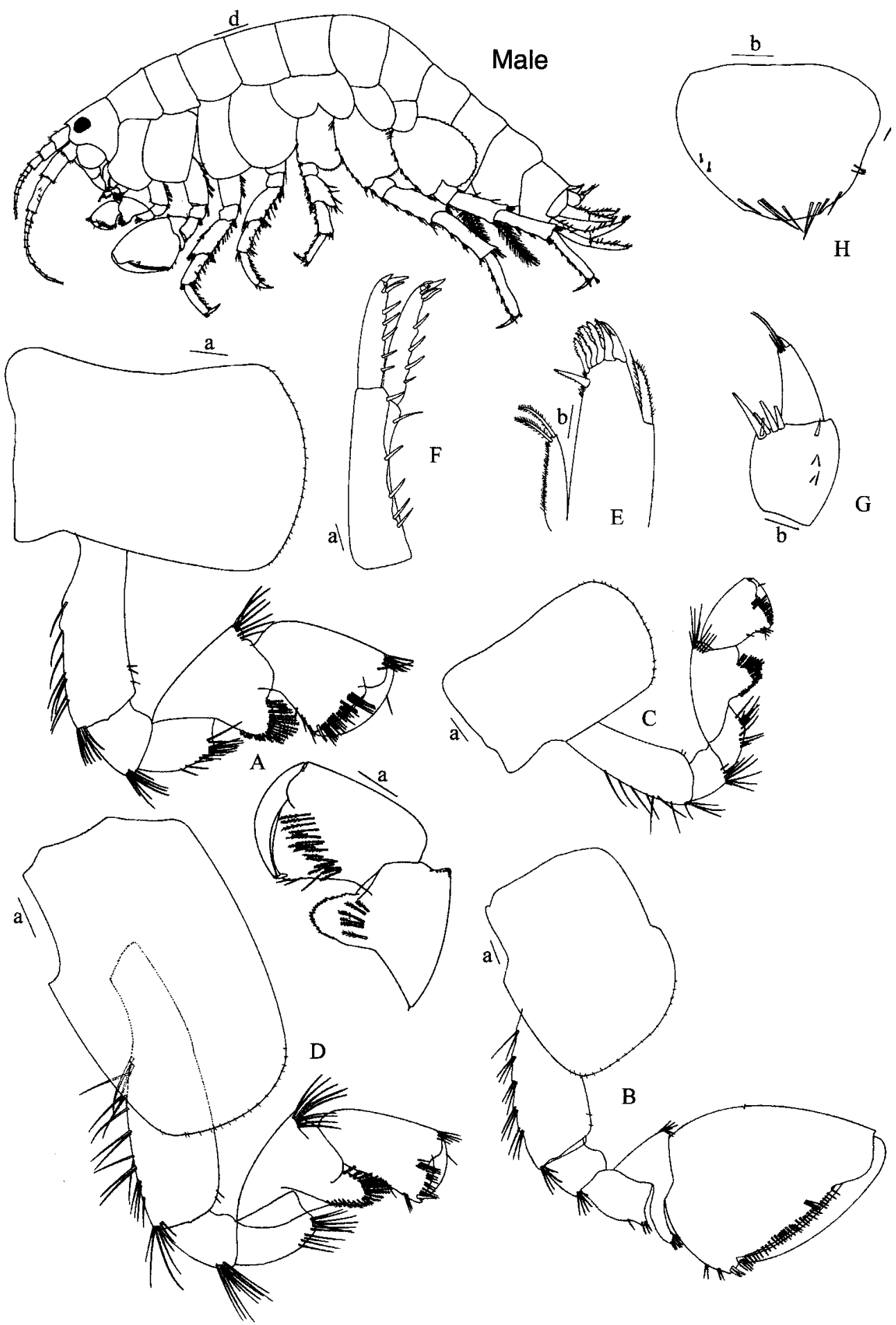

Fig. 5: Hyalella franciscae, male, length $12.8 \mathrm{~mm}$, female $11.4 \mathrm{~mm}$. Modified from González \& Watling (2003a). Symbols as in Fig. 4. The scale is indicated as a small bar on each appendices: "a" is equivalent to $192 \mu \mathrm{m}$; "b" is equivalent to $94 \mu \mathrm{m}$; "d" is equivalent to $481 \mu \mathrm{m}$.

Hyalella franciscae, macho, largo 12,8 mm, hembra 11,4 mm. Modificado de González \& Watling (2003a). Símbolos como en Fig. 4. La escala de tamaño esta indicada por una pequeña barra en cada apéndice: "a" es equivalente a $192 \mu \mathrm{m}$; "b" es equivalente a $94 \mu \mathrm{m}$; "d" es equivalente a $481 \mu \mathrm{m}$. 


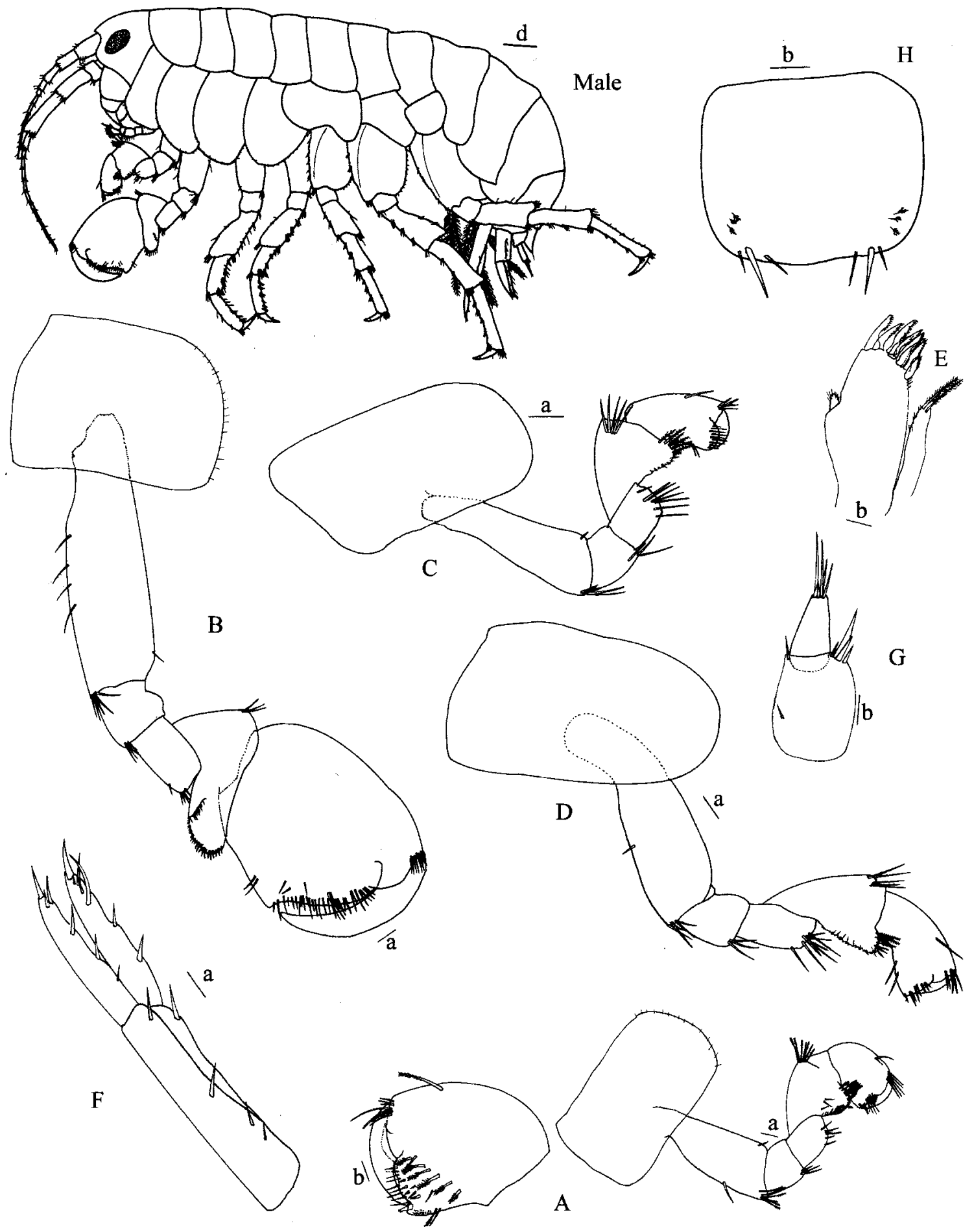

Fig. 6: Hyalella kochi male, length $6.9 \mathrm{~mm}$, female $5.5 \mathrm{~mm}$. Modified from González \& Watling (2001). Symbols as in Fig. 4. Scale as in Fig. 2.

Hyalella kochi macho, largo 6,9 mm, hembra 5,5 mm. Modificado de González \& Watling (2001). Símbolos como en Fig. 4. Escala de tamaño como en Fig. 2. 
Hyalella gracilicornis González, 1991a: 56 (in part).

Type locality: bofedal de Arabilla, Chile. Material Examined: bofedal de Arabilla, Arica; El Tatio, Salar de Punta Negra and Loa river in Antofagasta.

Diagnosis: body surface smooth. Coxa 4 excavated posteriorly. Eyes pigmented. Antenna 1 shorter than antenna 2. Antenna 2 less than half body length. Mandible incisor toothed. Maxilla 1 palp short, reaching less than half length the distance between base of palp and tip of setae on outer plate; inner plate slender, with two strong and pappose apical setae. Maxilla 2 inner plate with one strong pappose seta on inner margin. Gnathopod 1 propodus length less than two times maximum width (quadrangular), hammer shape, inner face with seven pappose setae, setose scales on disto-posterior and disto-anterior border. Gnathopod 2 propodus ovate, palm shorter than posterior margin, slope slightly oblique, anterior edge smooth. Peraeopods 3 and 4 merus and carpus posterior margin with three to four hind marginal clusters of short setae; propodus posterior margin with five to eight groups of setae. Uropod 3 peduncle with four strong distal setae; outer ramus shorter than peduncle, basal width two times or less tip of ramus. Telson as wide as long, apically truncated, with two widely apart, long simple setae, symmetrically distributed, occasionally with shorter setae close to the main setae. Sternal gills in segments 3 to 7 .

Characters of females that differ from males. Size, $5.5 \mathrm{~mm}$. Antenna 1 flagellum with six articles. Antenna 2 flagellum with eight articles. Gnathopod 1 similar in size, and same shape to gnathopod 2; similar to male gnathopod 1 in size and shape. Gnathopod 2 different from male gnathopod 2 in shape and smaller, propodus length two to three times maximum width, normally subchelate, palm transverse.

Habitat: freshwater, epigean, littoral.

Distribution in Chile: Guallatire, Arica to Salar de Punta Negra, Antofagasta.

Remarks: Hyalella kochi is common only at high altitude. It is very characteristic for the equal length of ramus and peduncle in uropod 3 and big ovoid eyes. It is found together with $H$. fossamancinii. Both species are common and the male-female ratio is $1: 1$. The amphipods collected by S. W. Garman on January 19, 1875 in Moro, Lake Titicaca, Perú and San Antonio, Pisagua, northern Chile, (the latter close to the localities examined here) were assigned by Faxon (1876) to Allorchestes dentata inermis. The two sets of specimens deposited in the
Museum of Comparative Zoology, Harvard University (USA) do not correspond to the same species. The specimens from Chile are closely related to $H$. kochi; however, a more detailed study of the specimens seems necessary. Hyalella kochi is a species of wide distribution in the Andes, it has been found in coastal waters of Lake Titicaca, living sympatrically with $H$. tiwanaku González \& Watling, 2003c, and in Huancayo, Perú, living sympatrically with $H$. pauperocavae González \& Watling, 2002a.

\section{Hyalella simplex Schellenberg, 1943 (Fig. 7)}

Hyalella simplex Schellenberg, 1943 (in part): 201. Hyalella knickerbockeri Schellenberg, 1931 (in part): 228-230, fig. 116; not Allorchestes knickerbockeri Bate, 1862: 36-37, plate VI, fig. 1; not Hyalella (Mesohyalella) simplex Schellenberg, 1943 in Bousfield, 1996: 192.

Hyalella species "S" Bousfield, 1996 (in part): 195-196, fig. 6 .

Hyalella curvispina Grosso \& Peralta, 1999: 90-94, figs. 46-68.

Hyalella simplex González \& Watling, 2003a:

Type material: type unknown or lost. Type locality: Punta Arenas, Chile. Material examined: Punta Delgada, Magallanes, Chile.

Diagnosis: body surface smooth. Coxa 4 excavated posteriorly. Eyes pigmented. Antenna 1 shorter than antenna 2. Antenna 2 less than half body length. Mandible incisor toothed. Maxilla 1 palp longer than wide, reaching half length the distance between base of palp and tip of setae on outer plate; inner plate slender, with two strong and pappose apical setae. Maxilla 2 inner plate with one strong pappose seta on inner margin. Gnathopod 1 propodus length less than two times maximum width (quadrangular), hammer shape, inner face with seven pappose setae, setose scales on disto-posterior and disto-anterior border. Gnathopod 2 propodus ovate, palm shorter than posterior margin, slope slightly oblique, anterior edge smooth. Peraeopods 3 and 4 merus and carpus posterior margin with four hind marginal clusters of short setae; propodus posterior margin with two to four groups of setae. Uropod 3 peduncle with three strong distal setae; outer ramus shorter than peduncle, basal width more than two times tip of ramus. Telson as wide as long, apically rounded, with two widely apart, strong setae, symmetrically distributed, no additional apical setae present. Sternal gills in segments 3 to 7 . 


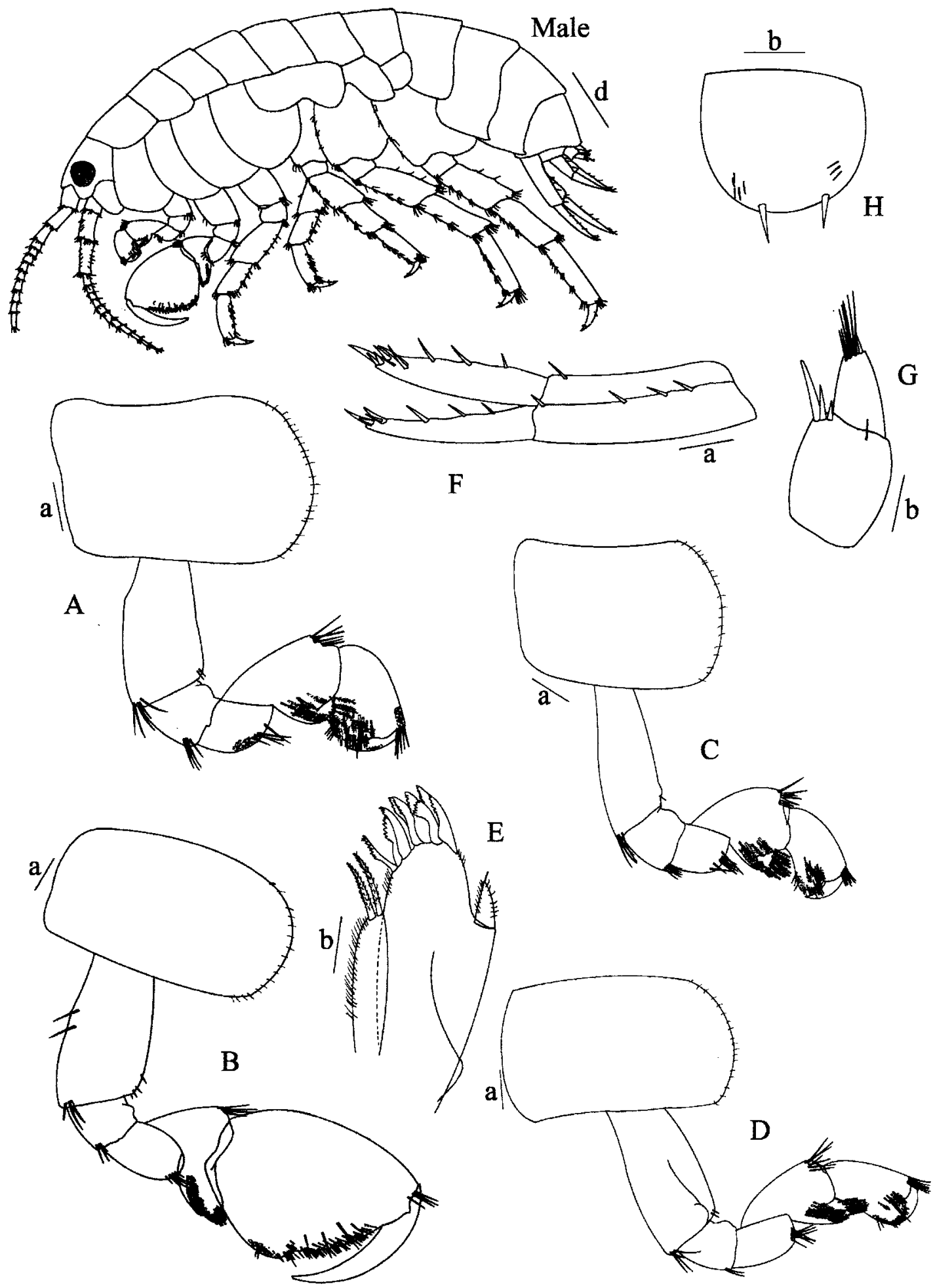

Fig. 7: Hyalella simplex, male $7.8 \mathrm{~mm}$, female $8.1 \mathrm{~mm}$. Modified from González \& Watling (2003a). Symbols as in Fig. 4. Scale as in Fig. 5

Hyalella simplex, macho, largo 7,8 mm, female 8,1 mm. Modificada de González \& Watling (2003a). Símbolos como en Fig. 4. Escala de tamaño como en Fig. 5. 
Characters of females that differ from males. Size, $8.1 \mathrm{~mm}$. Antenna 1 flagellum with nine articles. Antenna 2 flagellum with eleven to fourteen articles. Gnathopod 1 similar in size, and same shape to gnathopod 2; similar to male gnathopod 1 in size and shape. Gnathopod 2 different from male gnathopod 2 in shape and smaller, propodus length less than two times maximum width, normally subchelate, palm transverse.

Habitat: freshwater, epigean. Distribution: Punta Delgada, Lago Queillehue, Magallanes, Chile, South America.

Remarks: the distribution of $H$. simplex is confined to the extreme south of South America, where the "patagonica complex" dominates the freshwater habitat. The description by Schellenberg (1931) of $H$. knickerbockeri for Chile was later (Schellenberg 1943) considered a new species, $H$. simplex. The material studied by Schellenberg (1931) included specimens from several localities in Chile, Argentina including Isla Malvinas (Falkland islands), and Uruguay. The species pictured in his work correspond to the material from Punta Arenas (Chile). The material from Putabla and Quilpué (Chile) correspond to $H$. costera. Type material from Schellenberg's original sampling was not available, but material from the same localities was collected and analyzed. H. simplex differs from $H$. kochi in the shape and setation of telson, the longer palp in maxilla 1, the several connate setae on inner plate and wider article 2 of palp in maxilliped, and the longer propodus in female gnathopod 2. This species was mistakenly described as $H$. curvispina by Grosso \& Peralta (1999). H. simplex has sternal gills in segments 3 to $7, H$. curvispina in segments 2 to 7 . These authors in the description of this species include populations as far north as Concepción (Chile). In the samples analyzed in this work from that area, H. simplex was not present. Grosso \& Peralta (1999) based their identifications on the presence of curved setae on inner ramus of uropod 1. This character is common in several species with very different general morphologies and distribution of sternal gills.

\section{DISCUSSION}

The information gathered for this work from new material collected in Chile, and the examination of type material in most cases, indicates that the synonymies proposed by Barnard \& Barnard (1983) and the distributions proposed by
González (1991a, 1991b) are no longer valid. $H$. gracilicornis is a species from the Amazonian basin and its area of influence. The morphological characteristics of this species (González \& Watling 2003b) do not agree with any of the species found in Chile. Hyalella azteca has been mention for South America and Chile several times (Ruffo 1947, González 1991a, Villarroel \& Graziani 1995). However, the redescription of the species by González \& Watling (2002b) makes it clear that the morphology is not present in South America. Unfortunately, some countries have imported specimens of $H$. azteca from U.S.A. to be used in toxicological studies, that may have introduced the species into natural habitats. The azteca morphology has not been found for Chile yet. Hyalella andina most probably corresponds to $H$. fossamancinii, but it is not possible to validate it. $H$. simplex is not synonym with $H$. curvispina. The material reported by Schellenberg (1931) comprises and array of different species, the drawings and description in his publication correspond to $H$. simplex. Samples of $H$. curvispina from Argentina, Uruguay and Brazil indicates that the morphology, although variable, does not correspond with the ones present in Chile. The samples analyzed of $H$. araucana indicates that its distribution is restricted to areas near Punta Arenas (Chile) and probably toward the east into Argentina, this distribution agrees with the type locality of $H$. patagonica. Hyalella franciscae has a distribution northwest of Punta Arenas toward Torres del Paine National Park. The former $H$. patagonica (Cunningham, 1871) could be any of the species in the complex.

To summarize, we recognize seven species of Hyalella present in Chile ( $H$. simplex Schellenberg, 1943; H. fossamancinii, Cavalieri, 1959; H. kochi González \& Watling, 2001; H. chiloensis González \& Watling, 2001; H. costera González \& Watling, 2001; H. araucana Grosso \& Peralta, 1999; and H. franciscae González \& Watling, 2003a). The other four species previously mentioned for Chile are either not present or they are in the synonymy of one the above species. Further sampling of the Andean region, especially in northern Chile could find the species $H$. tiwanaku González and Watling, 2003c and H. pauperocavae González and Watling, 2002a now only known for Bolivia and Perú, respectively.

\section{LITERATURE CITED}

BARNARD JL \& CM BARNARD (1983) Freshwater Amphipoda of the world. I. Evolutionary patterns and II. Handbook and bibliography. Hayfield Associates, Mt. Vernon, Virginia, USA. 830 pp. 
BATE CS (1862) Catalogue of the specimens of Amphipodous Crustacea in the collection of the British Museum. British Museum (Natural History) London, United Kingdom. 399 pp.

BOUSFIELD EL (1996) A contribution to the reclassification of Neotropical freshwater Hyalellid amphipods (Crustacea: Gammaridea, Talitroidea). Bolletino del Museo Civico di Storia Naturale de Verona (Italy) 20: 175-224.

CAVALIERI F (1959) Una nueva especie de anfipodo de agua dulce (Crustacea, Anfipoda). Physis (Argentina) $21: 278-288$.

CUNNIGHAM RO (1871) XVII. Notes on the Reptiles, Amphibia, Fishes, Mollusca and Crustacea obtained during the voyage of H.M.S. "Nassau" in the years 1866-69. Transactions of the Linnean Society of London 27: 465-502.

FAXON W (1876) Exploration of Lake Titicaca by Alexader Agassiz and S.W. Garman. IV. Crustacea. Bulletin of the Museum of Comparative Zoology (USA) 3: 361-375.

GONZÁLEZ ER (1991a) Actual state of Gammaridean Amphipoda taxonomy and catalogue of species from Chile. Hydrobiologia 223: 47-68.

GONZÁLEZ ER (1991b) Talitroidea marinos y de agua dulce en Chile (Crustacea, Amphipoda). Estudios Oceanológicos (Chile) 10: 95- 111.

GONZÁLEZ ER \& L WATLING (2001) Three new species of Hyalella from Chile (Crustacea: Amphipoda: Hyalellidae). Hydrobiologia 464: 175-199.

GONZÁLEZ ER \& L WATLING (2002a) A new species of Hyalella from the Andes in Peru (Crustacea: Hyalellidae). Revista de Biología Tropical 50: 649-658.

GONZÁLEZ ER \& L WATLING (2002b) Redescription of Hyalella azteca from its type locality, Vera Cruz, Mexico (Amphipoda: Hyalellidae). Journal of Crustacean Biology 22: 173-183.

GONZÁLEZ ER \& L WATLING (2003a) A new species of Hyalella from the Patagonia, Chile, with the redescription of $H$. simplex Schellenberg, 1943 (Crustacea: Amphipoda). Journal of Natural History 37: 2077-2094.

GONZÁLEZ ER \& L WATLING (2003b) A new species of Hyalella from Brazil (Crustacea: Amphipoda), and redescriptions of three other species in the genus. Journal of Natural History 37: 2045-2076

GONZÁLEZ ER \& L WATLING (2003c) Two new species of Hyalella from Lake Titicaca, and redescriptions of four others in the genus (Crustacea: Amphipoda). Hydrobiologia 497: 181-204

GROSSO L \& M PERALTA (1999) Anfípodos de agua dulce sudamericanos. Revisión del género Hyalella
Smith. I. Acta Zoologica Lilloana (Argentina) 45: 79-98.

ORTMANN AE (1911) Crustacea of southern Patagonia. Reports of the Princeton University Expeditions to Patagonia, 1896-1899 (Zoology) 3: 635-667.

PHILIPPI RA (1860) Reise durch die Wueste Atacama auf Befehl der chilenischen regierung im sommer 1853-54 unternommen und beschreiben. Halle: Eduard Anton. $192 \mathrm{pp}$.

RUFFO S (1947) Studi sui crostaci anfipodi. XV. Su alcune speciedi anfipodi dell'Argentina e della Terra del Fuoco. Bolletino del Laboratorio di Entomologia Agraria di Portici (Italy) 7: 326-332.

SAUSSURE H (1858) Memoire sur divers crustaces nouveaux de Antilles et du Mexique. Memoire de la Societe Physique du Histoire Naturrelle, P2 14: 417-496.

SHOEMAKER CR (1942) A new species of Amphipoda from Uruguay and Brazil. Journal of the Washington Academy of Sciences 32: 80-82.

SCHELLENBERG A (1931) Gammariden and Caprelliden des Magellangebietes, Südgeorgiens und der Westantarktis. Further Zoological Results of the Swedish Antarctic Expedition 1901-1903 2: 1-290.

SCHELLENBERG A (1935) Fauna chilensis, Amphipoden von Chile und Juan Fernandez. Zoologische Jahrbbucher Abteilung fur Systematik 67: 225-234.

SCHELLENBERG A (1943) Susswasser amphipoden (Crust.). Beitrage zur Fauna Perus 2: 200-206.

SMITH S (1875) Report on Amphipod Crustaceans. Annual Report of the United States Geological and Geographical Survey of the territories, Embracing Colorado. The Exploration for the year 1873, by F.V.Hayden, Washington, Goverment Printing Office, 1874: 608-611.

STEBBING TRR (1906) Amphipoda I. Gammaridae. Das Tierreich 21: 1-806

STEBBING TRR (1888) Report on the Amphipoda collected by H. M. S. Challenger during the years 1873-1876. In Great Britain, Report on the Scientific results of the voyage of HMS. Challenger during the years 1873-1876. Zoology 29: 1-1737.

STEBBING TRR (1914) Crustacea from the Falkland islands collected by Mr. Rupert Vallentin. FLS. Pt. II. Proceedings of the Zoological Society of London 1: $341-378$.

STOCK JH \& D PLATVOET (1991) The freshwater Amphipoda of Falkland Islands. Journal of Natural History 25: 1469-1491.

VILLARROEL EJ \& CA GRAZZIANI (1995) Distribution of Hyalella azteca (Amphipoda: Hyalellidae) in Venezuela. Revista de Biología Tropical 43: 325. 


\section{APPENDIX 1}

Key to the species of Hyalella in Chile

Clave para la identificación de Hyalella en Chile

(Also included Hyalella pauperocavae, Hyalella tiwanaku and Hyalella curvispina)

1(0) Gnathopod 1 hatched shape (Fig. 1A) 2

Gnathopod 1 hammer shape (Fig. 2A) 4

2(1) Telson with several long apical setae (Fig. 5H) H. franciscae Telson with minute apical setae (Fig. 1I)

3(2) Palm of propodus in male gnathopod 1 shorter than posterior margin (Fig. 4A)

H. fossamancinii Palm of propodus in male gnathopod 1 longer than posterior margin (Fig. 1A)

4(1) Sternal gills present in segments 2 to 7 5

Sternal gills present in segments 3 to 7

5(4) Uropod 3 peduncle slender (rectangular)

H. curvispina

Uropod 3 peduncle quadrate H. tiwanaku

6(4) Telson wider than long, with several strong apical setae

H. pauperocavae

Telson longer than wide, with several long slender apical setae (Fig. 2I)

H. chiloensis

Telson as wide as long, with two main apical setae (Fig. 7H)

7(6) Ramus of uropod 3 shorter than peduncle (Fig. 7G) 8

Ramus of uropod 3 longer than peduncle (Fig. 3H) H. costera

8(7) Telson quadrate, with two main slender apical setae and four small accessory setae (Fig. 6H).. H. kochi Telson ovoid, with two strong apical setae (Fig. 7H) H. simplex 